Intersections

Canadian Journal of Music

Revue canadienne de musique
Intersections

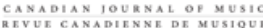

\title{
Exploring Decolonization, Music, and Pedagogy
}

\section{Editorial}

\section{Robin Attas et Margaret E. Walker}

Volume 39, numéro 1, 2019

Decolonizing Music Pedagogies

URI : https://id.erudit.org/iderudit/1075339ar

DOI : https://doi.org/10.7202/1075339ar

Aller au sommaire du numéro

Éditeur(s)

Canadian University Music Society / Société de musique des universités canadiennes

ISSN

1918-512X (numérique)

Découvrir la revue

Citer ce document

Attas, R. \& Walker, M. E. (2019). Exploring Decolonization, Music, and Pedagogy: Editorial. Intersections, 39(1), 3-20. https://doi.org/10.7202/1075339ar

(C) Canadian University Music Society / Société de musique des universités canadiennes, 2021
Ce document est protégé par la loi sur le droit d'auteur. L'utilisation des services d'Érudit (y compris la reproduction) est assujettie à sa politique d'utilisation que vous pouvez consulter en ligne.

https://apropos.erudit.org/fr/usagers/politique-dutilisation/ 


\title{
EXPLORING DECOLONIZATION, MUSIC, AND PEDAGOGY ${ }^{1}$
}

\author{
Robin Attas and Margaret E. Walker
}

The title of this issue, "Decolonizing Music Pedagogies," has two meanings. Perhaps the more obvious of these is the act or intention of decolonizing the pedagogies used in university music programs. But it can also point to the development of pedagogies that have the potential to do decolonizing work through their application in music courses. Neither interpretation leads to easy or pre-packaged methodologies or materials, and we are still left with many questions. What does it mean to decolonize music pedagogies? How might this be best approached and how should it perhaps not be approached? What might new music pedagogies that "do" decolonization work look like? How can we begin? How can we keep going?

This special issue of Intersections offers a few answers to these questions about decolonization, while recognizing that there are many more approaches. Pinning down a single definition of decolonization is itself impossible, given the variety of critical positions taken in theory and practice worldwide. Yet developing a single, monolithic definition is surely not a desirable goal. In our view, decolonization is a process not a product, and our various and shifting experiences, contexts, positions, and conversations can significantly affect our individual and collective understandings. The twelve authors writing here all offer their own interpretations of decolonizing pedagogies, and we appreciate their plurality, particularly the two Indigenous voices included in the collection. However, we, the two co-editors, recognize that there are many voices not represented in and through the conversations in this issue. The collection is certainly more local than global, for example, and includes only one article in French. Most of the authors are anglophone and many are white. We hope amongst our many aspirations for this publication that the articles presented here will invite many more voices to engage in further dialogue about pedagogy, scholarship, and decolonial teaching.

1 Our sincere thanks to Beverley Diamond and Alan Dodson for their comments on this introduction. We are also very grateful to the eighteen anonymous peer reviewers, the Intersections editorial team, and the MusCan Board for their assistance with and support of this special issue. 
We write as two white settler Canadian ${ }^{2}$ academics-one a musicologist/ ethnomusicologist (Margaret), the other a music theorist/educational developer (Robin). Our experiences inside and outside academia shape our perspectives, as do our intersectional identities, which have included both marginalized and mainstream positions within our respective disciplines and the broader society we live in. We share the privileged beginnings common to many musicians in the academy, including government-supported music classes in our schools, often expensive private music lessons in the Western art music style, and supportive middle-class families who took us to elite performances and encouraged our pursuit of higher education. We both completed post-secondary degrees at Canadian universities and have found ourselves employed at Queen's University in Kingston, Canada, on the traditional territories of the Anishinaabek and Haudenosaunee peoples. The stories of how we each became advocates for decolonization of music pedagogies are much less similar, but rather than take up space here with their telling, we want to shift the focus to you, the reader. In particular, we want to encourage those of you new to these ideas to join the conversation.

When we began work on this special issue with a call for papers sent out in the fall of 2018, there was no COVID-19, and a pandemic seemed only a topic for a dystopic movie. Between March and May 2020, however, it often seemed as if there were few other legitimate issues. Yet, as we, along with countless other teachers in Canada and the United States, struggled with emergency adjustments to teaching, we were constantly reminded of the importance of evaluating our music-teaching practices in the context of settler colonialism. Over the span of this issue's development, numerous global, national, local, and personal events have pulled our minds and hearts in different directions. Protests in solidarity with Indigenous struggles for sovereignty, demonstrations against anti-Black and anti-Indigenous racism and accompanying police violence, the sudden shift to remote teaching and public health lockdowns-all of these things had the potential to distract us from the work of this issue, but instead they sharpened our initial intentions. Educational decolonization, with its critical recognition of the enduring power imbalances, epistemological assumptions, and marginalization of experience in the academy, is a crucial and ongoing struggle that continues to deserve our vigorous attention. As global events continue to unfold in unpredictable ways, we are reminded that only sustained and deep attention will lead to sustained and deep change. We hope to inspire you to both attention and change.

In this issue, we are primarily interested in first steps, in creating an invitation for music professors, whether performers, composers, educators, historians, theorists, or ethnographers, to take up this work. We challenge those readers who have yet to begin and who may be asking "Why decolonize?" to

2 We call ourselves settlers in recognition of our ancestry from people who settled the land currently known as Canada without the permission of the Indigenous inhabitants, and also in acknowledgment of the ways in which we have benefitted, continue to benefit from, and are complicit in the past and present colonial practices of the Canadian nation-state. See Battell Lowman and Barker (2015). 
ask instead "Why not?" Whatever your answer we encourage you to treat this issue as a source of inspiration and guidance from colleagues who have taken those first steps. We also hope that those readers who have already begun to decolonize their teaching will find inspiration, support, and new insights and strategies. The articles themselves, written by a range of authors including several collaborations, include reflective essays, theoretical papers, and of course pedagogies worth sharing.

The articles and their pedagogies, however, need first to be placed in the context of decolonization and its interaction with universities and colleges. In this introduction we therefore offer starting places for three themes-terms and theories, the Canadian settler context, and post-secondary music programs. We then place the articles in dialogue with these themes, inviting readers to engage more deeply with the authors' work as they communicate their own projects and practices.

\section{Terms AND Theories}

The tangle of theoretical terms and concepts surrounding and embedded in discussions of decolonization can often deter even those of us with the best of intentions. Definitions are elusive and can often be contentious, "consisting of a heterogeneity of viewpoints, approaches, political projects and normative concerns" (Bhambra, Gebriel, and Nişancioğlu 2018, 2). Position and privilege, past and present shape understandings in complex ways. Given our focus on application in pedagogy, we will endeavour to keep our theorization practical.

Broadly, theorists and activists confront the impacts of European colonialism both globally and locally. ${ }^{3}$ Arising from the voyages of "discovery" that began in the late fifteenth century, colonial extraction, occupation, and eventual settlement followed the interests of the expanding European international trading companies. Although one can locate fleeting examples of equitable alliances, relationships, and treaties in the history of European expansion (as, for example, illustrated in Osterhammel 2018), the unfolding of the colonial project has left a much more devastating legacy of worldwide invasion, occupation, violence, and domination. Extracted wealth from the colonies poured back into Europe, and in the seventeenth and eighteenth centuries funded the blossoming of artistic and intellectual production usually identified as the Baroque, the Age of Reason, and the Enlightenment. Democracy, rationalism, capitalism, and public education flourished and prospered, predominantly through the support of economic success in far-off lands.

Although arguably simplistic, European colonial activities can be divided into examples of exploitation, with a primary goal of resource extraction and increased wealth for the metropole, and settlement, where the primary goal was appropriation of land for eventual immigrant ownership. Of course, many exploitation colonies also attracted settlers, and settler colonies were also the

3 We recognize the existence of many other colonial and imperial projects, past and present, but given our interest in music programs built around European art music, our focus here is on European colonialism. 
focus of resource extraction and export. Colonialism of both types also gave rise to theories of racial hierarchy and cultural evolution. Cultural historian Craig Steven Wilder puts it bluntly in his meticulously documented exposure of the role of African slavery and Indigenous disenfranchisement and genocide in the founding and funding of America's colleges and universities: "Racial ideas were born in the colonial world, in the brutal and deadly processes of empire building" (Wilder, 2013, 182). Validating the inequities of the colonial world, which existed in blatant conflict with Enlightenment ideals of rational humanism, freedom, and happiness, scientific racism arose and became embedded in the academy through the eighteenth and nineteenth centuries. It was only after the comparatively swift collapse of European imperial power in the twentieth century, through the gradual and often bloody emergence of independent nations from former colonies, that colonial theories of racial difference and social Darwinism began to be challenged through post-colonial frameworks.

Scholars often credit Frantz Fanon as the initial source for theoretical discussions of decolonization and post-colonial studies (Fanon 1963, 1965, 1967). Other important post-colonial theorists such as Edward Said (1978), Gayatri Spivak (1988), and Homi Bhabha (1994) troubled and disrupted many scholarly and artistic assumptions that remained rooted in largely unseen colonial epistemologies. This key point, that colonialism is not a historical moment in the past, but rather the foundation of ongoing social and economic inequities insidiously and often invisibly woven through both global and local relations, has resulted in the concept of "coloniality," the "long-standing patterns of power that emerged as a result of colonialism" (Maldonado-Torres 2007, 243). It is easy to see colonial violences as indignities that took place in the past and have largely healed in the post-colonial present. This perception is not accurate, and the continued imbalance of wealth and resources between the "developed" and "developing" worlds is only one example of coloniality in a supposedly post-colonial world. More specifically relevant to the topic of this issue is the coloniality embedded in access to education and the question of what knowledge systems and teaching contexts are privileged.

There is no post-colonial context, however, in locations like North and South America, Australia, and New Zealand where the colonizers remain. In Canada and the United States, modes of government, economics, and education are still firmly entrenched in the institutions of the settler populations, and scholars therefore discuss the complications of decolonization rather than post-colonialism. In particular, Tuck and Yang's foundational article, "Decolonization Is Not a Metaphor" (2012), powerfully establishes educational terms of reference: decolonization is not a metaphorical or philosophical shift in education, roughly equivalent to calls for diversity, inclusion, or justice. Rather, it requires action, personal and structural change, and fundamentally must be accompanied by the return of land to Indigenous peoples (7). Other scholars resist or complicate this strict focus on Indigenous/non-Indigenous relationships or reach beyond the North American context. Nelson Maldonado-Torres, for example, emphasizes the fight for decolonization among Black South Africans 
and also within his native Puerto Rico (2016), and Aileen Moreton-Robinson addresses her Aboriginal identity in the Australian context in her work (2003). These and other scholars focus on the global reach of the violences of the colonial project, and the discussion changes depending on the people and histories involved (see, among others, Battell Lowman and Barker 2015; Bhambra, Gebrial, and Nişancioğlu 2018; Moreton-Robinson 2015; Ndlovu-Gatshemi and Zondi 2016; Veracini 2010; and Wolfe 2006).

We who have edited this issue, and perhaps most of you who are reading it, remain settlers on occupied Indigenous lands that have in various degrees been "developed" through the labour of enslaved or colonized peoples. The term and concept of settler colonialism, like the use of the terms "coloniality" and "decoloniality" instead of "colonialism" and "decolonization,"4 emphasizes the present-tense, institutional, and structural nature of this concern. Not only did early colleges and eventual universities offer "a norm of instruction and training ... exported from Europe and ... imposed on the rest of humanity" (Abdi and Richardson 2008, 1; see also Willinsky 1998), they also were funded by wealth amassed through resource extraction, particularly the African slave trade. 5 Higher education, founded and funded through the colonial project, was by the nineteenth century repaying this support with "research" that seemingly absolved Europe of 200 years of domination, occupation, and violence. Moreover, many current academic disciplines, including musical studies, took form in the colonial context and continue to privilege and disseminate epistemologies and pedagogies from the nineteenth century.

Not surprisingly, a number of education scholars have therefore grappled with the question of whether such a colonial institution as the university can ever be decolonized. Mihesuah and Wilson (2004) and Tuhiwai Smith (2012), for instance, forefront the racism Indigenous peoples have faced within research projects involving them, and within the academic settings of which they are a part. In Reshaping the University: Responsibility, Indigenous Epistemes, and the Logic of the Gift, Rauna Kuokkanen (Sami) describes the means by which both academics and the university are complicit in the colonization of Indigenous peoples and places. She is worth quoting at length for her elucidation of the relationship between the eurocentric ${ }^{6}$ academy and Indigenous epistemologies:

As an institution, the academy supports and reproduces certain systems of thought and knowledge, and certain structures and conventions, that rarely reflect or represent Indigenous worldviews. In this way, it silences and makes invisible the reality of many Indigenous students. To a large extent, the academy remains founded on epistemological practices and traditions that are selective and exclusionary and that are reflective of and reinscribed

4 See Wolfe 2006 and Maldonado-Torres 2016.

5 The enslavement of Indigenous peoples by European settlers is an often erased part of North American colonial history.

6 We have deliberately used a lower-case $e$ for "eurocentric" to match our decision to use lower-case for "settler" and "white" and to capitalize "Indigenous," "Black," and other identities. See Cole$\operatorname{man}(2020)$. 
by the Enlightenment, colonialism, modernity, and, in particular, liberalism. These traditions, discourses, and practices have very little awareness of other epistemologies and ontologies, and offer them heavily restricted space at best. Even in the academic spaces that consider themselves most open to "changing the paradigm," individuals are often unwilling to examine their own blind spots. Nor are they willing to acknowledge either their privilege or their participation in academic structures and the various colonial processes of society in general. (Kuokkanen 2007, 1)

Further work explores the option of walking away or refusing the entire academic project (Grande 2017). Some scholars hypothesize that modernity itself, including the university, is beyond reform and can only be metaphorically hospiced (Andreotti et al. 2015), whereas others choose to reject entirely any compromise with the white settler majority (Tuck and Yang 2018; Tuhiwai Smith, Tuck, and Yang 2019). 7 We value these perspectives, particularly from Indigenous scholars, but nevertheless see our work as different although complementary. As white settlers, we feel an obligation to take up the task of educating our peers in order to reduce the burden of education on those who do not wish it. You, as readers, are encouraged to explore the many theoretical strands of this conversation with these and other authors, and to question your own motivations for seeking to do this work. Self-reflection, doubt, and honesty are important elements in the process and, as Bhambra, Gebrial and Nişancioğlu argue, "There is, as ever, more work to be done" $(2018,6)$.

\section{The Canadian Settler Context}

Since we write from and reside in the land currently known as Canada, and this journal and its sponsoring body, the Canadian University Music Society, are also based in that country, it seems appropriate to address this national context specifically. As in all settler colonies, the story of Indigenous-settler relations here is a long and painful one. It is sometimes tempting in Canada to see settler historical relationships with Indigenous peoples as comparatively well-meaning, if not innocent. Yet national policies that date from as far back as the 1869 Indian Act, although ostensibly focused on education and assimilation, have more often manifested themselves in attempted cultural and literal genocide. In recent years, however, the conversation has shifted in large part through the work of the Truth and Reconciliation Commission (TRC). The TRC took place between 2008 and 2015 as one of five components of the Indian Residential School Settlement Agreement, which came into effect in 2007 and was the largest class action suit in Canadian History. ${ }^{8}$ A simultaneous and

7 They write, "We refuse: justice projects which require us to prove humanity or worth; Justice projects which require us to frontload a lot of learning or consciousness-raising; Justice projects which require us to appeal to the people who abuse us; Justice projects which require us to gather an audience of white settlers who are presumed to have agency; Justice projects that presume compromise as the main avenue for achieving solidarity" (Tuck and Yang 2018, 8).

8 The IRSSA "recognized the damage inflicted on Indigenous peoples by residential schools in Canada and established a multi-billion-dollar fund to help former students in their recovery" (Marshall 2013b). See also Truth and Reconciliation Commission of Canada. 
ongoing grassroots protest, \#Idlenomore, raised public awareness of "Indigenous rights and sovereignty as well as environmental protection" (Marshall 2013a). The TRC's final report included ninety-four "Calls to Action," many of which address education. ${ }^{9}$

Initial responses to these calls have ranged in scope from general position statements (Barnard 2015) to longer lists of potential actions (as in Pete 2016) to analyses of theoretical pedagogical approaches (as in Andreotti et al. 2015). Terms such as "decolonization," "Indigenization," and "reconciliation" have in some work become even more contested than previously (Hill 2012; Garneau 2016). There is certainly a wealth of ideas in this literature, but many new to the conversation can still be left wondering where to begin, and many with more experience have found themselves frustrated by the lack of action. Similar to anti-racist activism in the United States, there have been both encouraging and disheartening developments in Canada, as the winter 2020 protests in solidarity with the Wet'suwet'en illustrate. Scholars have also begun noting both the varied definitions of "decolonization," "Indigenization," and "reconciliation" in the academy and also the danger of their tokenistic use (see, among others, Bopp, Brown, and Robb 2017; Gaudry and Lorenz 2018; Giroux 2017). Nevertheless, Canadian universities are continuing to work with governments to develop support for Indigenous students (Universities Canada n.d.). There also often seems to be a concerted effort by national and local media to include more Indigenous-written and Indigenous-focused content, and Indigenous and non-Indigenous activism is ongoing.

Most of these first steps, however, have engaged with theory, politics, and social action rather than pedagogy. While we understand that systemic change necessitates deep understanding and rigorous critique of underlying structures, we feel it is also crucial to demonstrate concrete and practical strategies for enacting decolonization in the specific context of the university classroom. If we wait for change from the top, we may wait a long time. We draw from our reading of the diverse sources named above, as well as from our lived experience, to advocate for the necessity that decolonization be not just theoretical, but practical, be not only words but also deeds. Undoing the systemic and institutional structures as well as changing our own individual hearts, minds, beliefs, and values is difficult but necessary work. But, like vines that grow over concrete buildings, gradually pulling away pieces of the artificial stone until the building collapses, we believe small actions can effect revolutionary change.

\section{Post-Secondary Music Programs and Decolonizing}

Musical studies in higher education offer considerable room for such action. Although many faculty members teaching in music programs in Canada and the United States have discussed and undertaken curricular revisions in recent

9 There are four calls (nos. 11, 16, 62, and 65) that specifically address post-secondary education, calling for increased funding for Indigenous students, collaborative research on reconciliation, and curricular changes that include primary and secondary school teacher training and the creation of Aboriginal language degree and diploma programs (TRCC, Calls to Action 2015). 
years, undergraduate music study generally remains one of the most conservative and reactionary disciplines in post-secondary education. The standard Bachelor of Music and BA Major in Music curriculum remains centred almost entirely upon the study of the elite concert music of Europe and its diaspora, a music more often identified as Western classical or art music. Usually proudly eurocentric and dedicated to the performance, analysis, and history of composed repertoire written largely by white, male composers, North American music programs have a desperate need for pedagogical reforms to address multiple issues of equity and representation. Many of the events and initiatives we draw attention to below, therefore, seemingly conflate decolonization with diversity, inclusion, feminism, anti-racism, and a host of other social justice initiatives. Tuck and Yang's admonishment often seems more aspirational than practical when applied to music studies, as even a simple recognition of the inherent whiteness of standard post-secondary music programs can sometimes seem an enormous first step for faculty, staff, and students. ${ }^{10}$

Most fields of music studies have seen some diversification of repertoire and research methods. Yet these still overwhelmingly arise from eurocentric perspectives and do not necessarily find their way into the foundational or core courses. Tuck and Yang's critique here is more apt: diversity of repertoire does not equal decolonial theory or practice. Furthermore, the conception of music as an art object, capable of being studied and analyzed apart from its emotional, spiritual, or embodied realities (which indeed can be seen as detrimental to scholarly work) is embedded deeply in European colonial epistemologies and academic history. Music history, theory, and performance courses in North American universities privilege European art music repertoire, notation, and a conception of music as a sound object composed of discrete elements that can be pulled apart, even dissected in order to "understand" it. As Margaret's recent work on decolonizing music history shows, these foundational courses date from late nineteenth-century European and North American conservatories and colleges (Walker 2020). This standardization of curriculum dates not only from the same period as the institutionalization of musicology as a legitimate field of academic study, but also from the time when European imperial occupation covered about 70 per cent of the globe (see also Karnes 2008 and Morrison 2019, 781-2). Robin's work also focuses on decolonizing core courses, although in the field of music theory (Attas 2019a; see also 2019b; and Attas and Nickleson 2018). As her work emphasizes, although elective courses can offer an easier starting place, since expected content and learning outcomes are less fixed, working to decolonize the core curriculum should affect student learning at a deeper and more wide-reaching level, and, crucially, demonstrates a commitment to meaningful change.

Whether aimed at required or elective elements, initiatives addressing curricular or disciplinary reform in music have increased in the academy in recent years. These have been motivated by a variety of concerns, including race

10 Readers interested in learning more about white privilege and white fragility might turn to McIntosh (1989) and DiAngelo (2018). 
and ethnicity (Ewell 2020; Guerrero et al. 2007; Hisama 2016, 2018a), diversity (Epstein et al. 2019; Ingraham et al. 2017; Madrid 2017), and broader goals of modernization or updating the curriculum (Campbell et al. 2014; Moore 2017; Hisama 2018b), along with decolonization directly (Levitz 2017; Chávez and Skelchy 2019; Stimeling and Tokar 2020; Walker 2020). ${ }^{11}$ Each semi-autonomous subdiscipline of music has members who are addressing curricular reform and increasingly includes power, race, and colonialism. Research in music education, with its investment in communities and social issues, in addition to expertise in pedagogical research and reform, has perhaps been most prolific (see, among many other examples, Bradley 2006, 2012, 2017; Hess 2015, 2017; Shifres and Rosabal-Coto 2017; Rosabal-Coto 2019). Musicology and music theory have joined the struggle more recently with items such as "Music, Race and Ethnicity," the special issue of the Journal of the American Musicological Society (Lewis and Calico 2019), keynote addresses at the Society for Music Theory (West Marvin et al. 2019) and the Canadian University Music Society (Robinson 2019), and two open letters from Project Spectrum (Reed et al. 2020a, 2020b). Nevertheless, such initiatives and calls to action still seem largely disconnected from the mainstreams of our fields and undergraduate teaching practice in the classroom. Although we are optimistic about what seems to be a groundswell of sincere interest, music studies in higher education remain fundamentally embedded in their white and colonial origins.

\section{Filling IN THE GAPS}

"As much as the discourse of decolonization has been embraced by the social sciences over the last decade, the decolonial project rarely gets beyond the conceptual or metaphorical level" (Tuck and Ree 2013, 647).

In the discussions of decolonization initiated through music academic societies and referenced above, we note two common yet significant gaps. The first is a lack of attention on music students-learners-not only as implicated in the work of decolonization but also as partners invited into the conversation. The second is an emphasis on theoretical positions rather than practical actions, or in other words, on critical theory rather than praxis. Attention to pedagogy, of course, varies across the music disciplines, and the shift from teacher-centred pedagogy to learner-centred pedagogy (heralded in higher educational research since the mid-199os by Barr and Tagg 1995, among others) is still only gradually being adopted across the academy. The emphasis on theoretical engagement over practical solutions in decolonial scholarship is also understandable, and given the entrenchment of colonial histories, methodologies, and values in the academy, disciplinary critique plays an important role in decolonization. Yet new theories and broad calls for action seem ineffective, if not meaningless, if learners themselves are not involved in the change.

11 This remains an incomplete list, and we are encouraged also by the number of new and forthcoming projects, presentations, and publications that address these and other crucial issues in the musical academy. 
It is our work in the classroom and the studio that shapes future teachers, as well as musicians, composers, and researchers. As scholars ranging from historian John Willinsky to feminist theorist and activist bell hooks have clarified, not only are research and education key agents of the colonial project (Willinsky 1998), they also have vast potential as crucial places to enact social change (hooks 1995, 2003). Drawing also on the work of Mi'qmaw education scholar Marie Battiste (2013), we see the work in decolonizing music pedagogies as two-fold. Music instructors must recognize, name, and expose the eurocentric values at the heart of North American post-secondary music study. And music instructors must recognize the value of multiple knowledge systems, beliefs, values, and practices in music-all of which are just as valid as Western ones. As our students, who are emergent teachers, professors, musicians, and scholars, pass through our classrooms and studios, these values will shape what they in turn pass on to their students, just as Western European values have shaped our teaching for centuries.

\section{Pedagogies, Strategies, Reflections}

Several pages above, we invited you, our readers, to ask not "why" but "why not" decolonize. Yet we recognize that the most pressing question is probably not "why" but "how." We know that this is a difficult topic that requires a great deal of rethinking, and we have also struggled with these questions. Decolonizing music study may be most unsettling in that it calls upon us to re-examine something that we love-music-and to question how we were taught and what we absorbed as we learnt. Yet questioning is not the same as rejecting, and the twelve authors of these seven articles and final open letter offer diverse ideas that will be both helpful and challenging.

Our issue opens with an article by D. Linda Pearse, "Expanding the University Music Ensemble: Lessons from an Intercultural Artistic Collaboration." Pearse applies lessons from an intercultural artistic collaboration How Do We Listen? to propose six teaching strategies for ensemble courses in music programs, along the way demonstrating how theoretical literature on the decolonization of education can be fruitfully applied to the specific case of university music programs. Making connections is not as hard as it seems; the sort of perceptive self-reflection and continued learning journey that Pearse demonstrates, on the other hand, takes a lot of (very necessary) work.

Alexa Woloshyn's "Decolonizing Desires and Unsettling Musicology: A Settler's Personal Story of Researching and Teaching Indigenous Music at an American University" takes the conversation about decolonization of music education to the level of a single course, in this case a graduate musicology seminar. Like Pearse, Woloshyn uses theoretical literature to spark self-reflection during ongoing efforts to unsettle her settler self, and she is candid and critical about the successes and challenges posed by her course design and implementation. By weaving her students' own voices within her critique, Woloshyn reminds readers of the impact that teaching decisions have on student learners. 
Both Pearse and Woloshyn discuss decolonization of music curricula within the context of Indigenous-settler relationships in the territories currently known as Canada and the United States. Travis D. Stimmeling and Sophia M. Enriquez engage with a different set of relationships when they consider the role of Appalachian bluegrass music within a Western art music-dominated music program in "Building Relationships, Sustaining Communities: Decolonial Directions in Higher Ed Bluegrass Pedagogy." They focus on the bluegrass jam session as a music ensemble pedagogy that is decolonial and inclusionary in that it elevates and fosters local practices and relationships, even as it continues to perpetuate elements of settler-colonialism in the West Virginia higher education context in which they write.

Quintina Carter-Ényì, Aaron Carter-Ényì and Kevin Nathaniel Hylton also engage with the treatment of marginalized cultures within the white settler-dominant world of higher education in the United States in "How We Got into Drum Circles, and How to Get Out: De-essentializing African Music." Beginning with an insightful history of the ubiquitous North American drum circle, they then share a creative solution. The article is clear in "calling out" the racist nature of American (and, one imagines, Canadian) music schools' often superficial engagement with African musics, and the Africana Music Experiential Pedagogy (AMEP) program they have developed to challenge this situation offers an engaging alternative.

Our next article shifts continents again, exploring decolonial pedagogies from another colonized part of the world while still rooting its critique in a North American viewpoint. Gillian Irwin's "Decolonization in 'Wild Schools': Local Music Pedagogies in Indonesia's Taman Siswa School System" describes the history of an anti-colonial school, the Taman Siswa, exploring the motivations of its founders and teachers and its role within Indonesian history and culture. In providing such a detailed discussion of this specific case, Irwin's article provokes questions about more general topics, including lessons in the subtleties of decolonization in local contexts and the pedagogical strategies music institutions might take as they engage in this work.

Many of the articles in this collection propose decolonizing music pedagogies by considering repertoires beyond Western art music. Gabriel Dharmoo's reflective paper "Reflets de la colonialité dans la scène des musiques nouvelles" brings us back into Western art music, but with a tight focus on the contemporary art music of a particular location, the city of Montreal. Dharmoo draws on extensive personal experiences to raise provocative questions grouped around a series of key themes, modelling (and thus encouraging) self-reflection, which is an important component of taking decolonizing actions.

We leave the last word amongst our peer-reviewed contributions for an article on an Indigenous student's experiences in a post-secondary music program. Highlighting student voices in educational research is unfortunately still all too rare, and in a decolonizing context it is even more critical to include student voices when they are from colonized communities. Kendra Jacque and Ellen Waterman's “The Long and Narrow Road: An Inuit Student's Journey through Post-Secondary Music" uses Jacque's own story as both a single example of one 
individual's experiences, and a means to comment on and connect to the experiences of Indigenous students in post-secondary education in Canada more broadly. By shifting from the particular to the general, from the microcosm to the macrocosm, the authors build a compelling case for the numerous changes they recommend. Additionally, the joint authorship model they use is an exemplar of how non-Indigenous music academics might use their positions to respect and celebrate music students whose voices have been marginalized in higher education music programs.

Our special issue concludes with an open letter from Stó:lō scholar and Canada Research Chair Dylan Robinson, addressed directly to the deans, directors, department heads, and faculty members working in university music programs. Robinson's calls to action and crucially to accountability are not only clear and direct, but also presented with increasing urgency. As he "calls in" all of us who teach in and administer music programs, he connects to key themes in the issue, including the need to dismantle the embedded colonial structures in entrance audition and core course requirements and the necessity of teaching multiple epistemologies, analytical methods, and ways of listening. Robinson's letter is hard hitting, but nonetheless presents practical advice that connects productively with the individual pedagogies of the articles.

We have positioned this special issue as a collection of starting places for decolonization of music pedagogies, and in reading the articles that follow, anticipate that you will find many recommendations for places to begin your own work. Yet the variety and specificity of the examples might seem overwhelming. So often, we encounter faculty who are excited about the process of decolonization but unsure about how to take the first steps. We will end, therefore, with three broad recommendations that we see emerging from this collection of articles.

Connect with the local. Many of our authors describe the music happening in local communities. What sorts of music are connected to the community surrounding your institution, now and in the past? Who is making that music? Are those people and those musics being included in your institution? The notion of academia as an ivory tower shut off from the world around it is an old one, and this is not the first time someone has advocated for dismantling that isolationist structure. But with music programs specifically, looking to historical and contemporary local music scenes of all genres is a desperately needed mode of change.

Take the time to discover the origins of what and how you teach. This includes the sources of music, information, pedagogies, and curricula. What are the sources and mediations of what we know? What messages about culture, values, race, or meaning are embedded in how we relay information or how we assess it? We encourage you to challenge received wisdom and methods-know their journey and critique it.

Listen both closely and broadly. Here we mean first the specific musical listening that so many of us engage in and use for both learning and assessment in many of our classes. We advocate for listening differently as a decolonial practice. We are cautious, given Dylan Robinson's critical evaluation of damaging 
colonial listening habits in Hungry Listening (2020). But we also mean a wide range of careful listening to other people and alternate voices, both human and otherwise. Through hearing the voices of a young Indonesian music student, a Wolastoqew musical collaborator, or the students in our classrooms (Indigenous and non-), we will open not only our ears but also our pedagogies.

In our own practice and throughout the issue, we are reminded time and again that decolonization is a process, not a product. We hope that this special issue inspires you to begin or continue your own process and to take not just a single step, but a lifelong journey. A mark of this issue's success, however, would be that its articles become in part historical artifacts, their arguments incomplete, irrelevant, and outdated, although their pedagogies ideally still vibrant. May the conversation continue.

\section{REFERENCES}

Abdi, Ali H., and George Richardson. 2008. "Foreword." In Decolonizing Democratic Education: Trans-Disciplinary Dialogues, edited by Ali H. Abdi and George Richardson, 1-11. Rotterdam: Sense Publishers.

Andreotti, Vanessa de Oliveira, Sharon Stein, Cash Ahenakew, and Dallas Hunt. 2015. "Mapping Interpretations of Decolonization in the Context of Higher Education." Decolonization: Indigeneity, Education \& Society 4 (1): 21-40.

Attas, Robin. 2019a. "Music Theory as Social Justice: Pedagogical Applications of Kendrick Lamar's To Pimp a Butterfly.” MTO: A Journal of the Society for Music Theory 25 (1). https://mtosmt.org/issues/mto.19.25.1/mto.19.25.1.attas. html.

.2019b. "Strategies for Settler Decolonization: Decolonial Pedagogies in a Popular Music Analysis Course." Canadian Journal of Higher Education 49 (1): 125-39. https://journals.sfu.ca/cjhe/index.php/cjhe/article/view/188281.

Attas, Robin, and Patrick Nickleson. 2018. "Decolonizing Music Pedagogy: Two Settler Perspectives on the Undergraduate Music Curriculum." Presented as part of the seminar "On the Academic Pipeline." American Musicological Society Annual Meeting. San Antonio, TX, 2 November 2018.

Barnard, David T. 2015. "The Role of Canada's Universities in Reconciliation." Universities Canada.https://www.univcan.ca/media-room/media-releases/ david-t-barnard-the-role-of-canadas-universities-in-reconciliation/.

Barr, Robert B., and John Tagg. 1995. "From Teaching to Learning: A New Paradigm for Undergraduate Education." Change 27 (6): 13-26.

Battell Lowman, Emma, and Adam Barker. 2015. Settler: Identity and Colonialism in 21st Century Canada. Black Point, NS: Fernwood Publishing.

Battiste, Marie. 2013. Decolonizing Education: Nourishing the Learning Spirit. Saskatoon, SK: Purich Publishing.

Bhabha, Homi. 1994. The Location of Culture. New York: Routledge.

Bhambra, Gurminder K., Dalia Gebrial, and Kerem Nişancıoğlu. 2018. "Introduction: Decolonizing the University?" In Decolonizing the University, edited by Bhambra, Gebrial, and Nişancioğlu, 1-15. London: Pluto. 
Bopp, Michael, Lee Brown, and Jonathan Robb. 2017. "Reconciliation within the Academy: Why Is Indigenization So Difficult?" Four Worlds Centre for Developmental Learning. http://www.fourworlds.ca/news.html.

Bradley, Deborah. 2006. "Music Education, Multiculturalism, and Anti-Racism: 'Can We Talk?'” Action, Criticism, and Theory for Music Education 5 (2). http://act.maydaygroup.org/articles/Bradley5_2.pdf.

- 2012. "Good for What, Good for Whom?: Decolonizing Music Education Philosophies." In The Oxford Handbook of Philosophy in Music Education, edited by Wayne D. Bowman and Ana Lucía Frega, 409-33. New York: Oxford University Press.

_ 2017. "Standing in the Shadows of Mozart: Music Education, World Music, and Curricular Change." In College Music Curricula for a New Century, edited by Robin D. Moore, 205-21. New York: Oxford University Press.

Campbell, Patricia Shehan, David Myers, Ed Sarath, Juan Chattah, Lee Higgins, Victoria Lindsay Levine, David Rudge, and Timothy Rice. 2014. Transforming Music Study from Its Foundations: A Manifesto for Progressive Change in the Undergraduate Preparation of Music Majors. Missoula, MT: College Music Society.

Chávez, Luis, and Russell P. Skelchy. 2019. "Decolonization for Ethnomusicology and Music Studies in Higher Education." Action, Criticism, and Theory for Music Education 18 (3): 115-43. https://doi.org/10.22176/act18.3.115.

Coleman, Nancy. 2020. "Why We're Capitalizing Black." New York Times, 5 July. https://www.nytimes.com/2020/07/05/insider/capitalized-black.html.

DiAngelo, Robin. 2018. White Fragility: Why It's So Hard for White People to Talk About Racism. Boston: Beacon.

Epstein, Louis Kaiser, Taylor Okonek, and Anna Perkins. 2019. "Mind the Gap: Inclusive Pedagogies for Diverse Classrooms," Journal of Music History Pedagogy 9 (2): 119-72.

Ewell, Philip. 2020. "Music Theory's White Racial Frame: Confronting Racism and Sexism in American Music Theory." https://musictheoryswhiteracialframe.wordpress.com/.

Fanon, Frantz. 1963. The Wretched of the Earth. New York: Grove.

—.1965. A Dying Colonialism. New York: Grove.

—.1967. Black Skin, White Masks. New York: Grove.

Garneau, David. 2016. "Imaginary Spaces of Conciliation and Reconciliation: Art, Curation, and Healing." In Arts of Engagement: Taking Aesthetic Action in and beyond the Truth and Reconciliation Commission of Canada, edited by Dylan Robinson and Keavy Martin, 21-41. Waterloo, ON: Wilfrid Laurier University Press.

Gaudry, Adam, and Danielle Lorenz. "Indigenization as Inclusion, Reconciliation, and Decolonization: Navigating the Different Visions for Indigenizing the Canadian Academy." Alter Native: An International Journal of Indigenous Peoples 14 (3): 218-27. https://doi.org/10.1177/1177180118785382. 
Giroux, Monique. 2017. "If 'Indigenizing' Education Feels This Good, We Aren't Doing It Right." The Conversation. https://theconversation.com/ if-indigenizing-education-feels-this-good-we-arent-doing-it-right-87166.

Grande, Sandy. 2018. "Refusing the University." In Toward What Justice: Describing Diverse Dreams of Justice in Education, edited by Eve Tuck and $\mathrm{K}$ Wayne Yang, 47-65. New York: Routledge.

Guerrero, Jeannie Ma, YouYoung Kim, Sumanth Gopinath, Jairo Moreno, and Horace Maxile. 2007. "Ethnic Diversity in Music Theory: Voices from the Field." Society for Music Theory Annual Meeting, Baltimore, OH, 17 November.

Hess, Juliet. 2015. "Decolonizing Music Education: Moving beyond Tokenism." International Journal of Music Education 33 (3): 336-47.

- 2017. "Equity and Music Education: Euphemisms, Terminal Naivety, and Whiteness." Action, Criticism, and Theory for Music Education 16 (3): 15-47. https://doi.org/10.22176/act16.3.15.

Hill, Elina. 2012. "A Critique of the Call to 'Always Indigenize!" Peninsula: A Journal of Relational Politics 2 (1). https://journals.uvic.ca/index.php/ peninsula/article/view/11513.

Hisama, Ellie. 2016. "On Race/Ethnicity in the Profession." In "Colloquy: Race, Ethnicity, and the Profession," Musicology Now. 1 December. http://www. musicologynow.org/2016/12/colloquy-race-ethnicity-and-profession.html.

—. 2018a. "Considering Race and Ethnicity in the Music Theory Classroom." In The Norton Guide to Teaching Music Theory, edited by Rachel Lumsden and Jeffrey Swinkin, 252-67. New York: W. W. Norton.

-2018b. "Power and Equity in the Academy: Change from Within." Current Musicology 102:81-92.

Ingraham, Mary, Karen Burke, Stefan Sunadan Honish, Nasim Niknafs, Dylan Robinson, and Yun Emily Wang. 2017. "Diversity in Canadian Post-Secondary Music Faculties: Voices from the Field." Roundtable presented at "Canada 150: Music and Belonging," Canadian University Music Society Annual Conference, Toronto, 27 May.

hooks, bell. 1995. Teaching to Transgress: Education as the Practice of Freedom. New York: Routledge.

-2003. Teaching Community: A Pedagogy of Hope. New York: Routledge.

Karnes, Kevin C. 2008. Music, Criticism, and the Challenge of History. New York: Oxford University Press.

Kuokkanen, Rauna. 2007. Reshaping the University: Responsibility, Indigenous Epistemes, and the Logic of the Gift. Vancouver: UBC Press.

Levitz, Tamara. 2017. "Decolonizing the Society for American Music." Bulletin of the Society of American Music 48 (3): 1-13.

Lewis, George E., and Joy H. Calico, eds. 2019. "Music, Race and Ethnicity." Special issue, Journal of the American Musicological Society 72 (3).

Madrid, Alejandro. 2017. "Diversity, Tokenism, Non-Canonical Musics, and the Crisis of the Humanities in U.S. Academia." Journal of Music History Pedagogy 7 (2): 124-30. 
Maldonado-Torres, Nelson. 2007. "On the Coloniality of Being: Contributions to the Development of a Concept." Cultural Studies 21 (2-3): 240-70.

- 2016. "Outline of Ten Theses on Coloniality and Decoloniality." Fondation Frantz Fanon. http://fondation-frantzfanon.com/ outline-of-ten-theses-on-coloniality-and-decoloniality/.

Marshall, Tabitha. 2013a. "Idle No More." The Canadian Encyclopedia. https:// www.thecanadianencyclopedia.ca/en/article/idle-no-more.

— 2013b. "Indian Residential Schools Settlement Agreement." The Canadian Encyclopedia. https://www.thecanadianencyclopedia.ca/en/article/ indian-residential-schools-settlement-agreement.

McIntosh, Peggy. 1989. "White Privilege: Unpacking the Invisible Knapsack." Seed: The National Seed Project. https://nationalseedproject.org/ Key-SEED-Texts/white-privilege-unpacking-the-invisible-knapsack.

Mihesuah, Devon Abbott, and Angela Cavender Wilson, eds. 2004. Indigenizing the Academy. Lincoln: University of Nebraska Press.

Moore, Robin, ed. 2017. College Music Curricula for a New Century. New York: Oxford University Press.

Moreton-Robinson, A. 2003. "I Still Call Australia Home: Indigenous Belonging and Place in a White Postcolonizing Society." In Uprootings/Regroundings: Questions of Home and Migration, edited by S. Ahmed, C. Castaneda, A. Fortier, and M. Sheller, 23-40. Berg: Oxford.

Moreton-Robinson, Eileen. 2015. The White Possessive: Property, Power, and Indigenous Sovereignty. Minneapolis: University of Minnesota Press.

Morrison, Matthew D. 2019. "Race, Blacksound, and the (Re)Making of Musicological Discourse." Journal of the American Musicological Society 72 (3): $781-823.10 .1525 /$ jams.2019.72.3.781.

Ndlovu-Gatshemi, Sabelo J., and Sephamandla Zondi, eds. 2016. Decolonizing the University, Knowledge Systems and Disciplines in Africa. Durham, NC: Carolina Academic Press.

Osterhammel, Jügen. 2018. Unfabling the East: The Enlightenment's Encounter with Asia, translated by Robert Savage. Princeton, NJ: Princeton University Press.

Pete, Shauneen. 2016. "10o Ways: Indigenizing \& Decolonizing Academic Programs." Aboriginal Policy Studies 6 (1): 81-9. https://doi.org/10.5663/aps. v6i1.27455.

Reed, Allisandra, Anna Gatdula, Catrina Kim, Clifton Boyd, and Laurie Lee. 2020a. "Open Letter to the AMS from Project Spectrum." Project Spectrum. https://projectspectrum.com/open-letters/.

— 202ob. "Open Letter to the SMT after 'Reframing Music Theory' from Project Spectrum." Project Spectrum. https://projectspectrum.com/ open-letters/.

Robinson, Dylan. 2019. “éy kws hákw’elestset te s'í:wes te siyolexwálh.” Keynote lecture. Canadian University Music Society Annual Conference, Vancouver, 5 June.

- 2020. Hungry Listening: Resonant Theory for Indigenous Sound Studies. Minneapolis: University of Minnesota Press. 
Rosabal-Coto, Guillermo, ed. 2019. "Decolonization." Special issue, Action, Criticism and Theory for Music Education 18 (3). http://act.maydaygroup. org/volume-18-issue- $3 /$.

Said, Edward. 1978. Orientalism. New York: Random House.

Shifres, Favio, and Guillermo Rosabal-Coto, eds. 2017. "Hacia una educación musical decolonial en y desde Latinoamérica." Special issue, Revista Internacional de Educación Musical 5. https://revistaeducacionmusical.org/index.php/rem1.

Spivak, Gayatri. 1988. Can the Subaltern Speak? Basingstoke, UK: Macmillan.

Stimeling, Travis D., and Kayla Tokar. 2020. "Narratives of Musical Resilience and the Perpetuation of Whiteness in the Music History Classroom." Journal of Music History Pedagogy 10 (1): 20-38. http://www.ams-net.org/ojs/ index.php/jmhp/.

Tuhiwai Smith, Linda. 2012. Decolonizing Methodologies. 2nd ed. London: Zed Books.

Tuhiwai Smith, Linda, Eve Tuck, and K. Wayne Yang. 2019. Indigenous and Decolonizing Studies in Education: Mapping the Long View. New York: Routledge.

Truth and Reconciliation Commission of Canada. https://www.rcaanc-cirnac. gc.ca/eng/1450124405592/1529106060525 and https://www.rcaanc-cirnac. gc.ca/fra/1450124405592/1529106060525.

C.Calls to Action. 2015. http://trc.ca/assets/pdf/Calls_to_Action_English2. pdf and http://www.trc.ca/assets/pdf/Calls_to_Action_French.pdf.

Tuck, Eve, and C. Ree. 2013. "A Glossary of Haunting." In the Handbook of Autoethnography, edited by Stacey Holman Jones, Tony E. Adams, and Carolyn Ellis, 639-58. New York: Routledge.

Tuck, Eve, and K. Wayne Yang. 2012. "Decolonization Is Not a Metaphor." Decolonization: Indigeneity, Education \& Society 1 (1): 1-40. https://jps.library. utoronto.ca/index.php/des/article/view/18630.

. 2018. "Introduction." In Toward What Justice? Describing Diverse Dreams of Justice in Education, edited by Tuck and Yang, 1-17. New York: Routledge.

Universities Canada. n.d. "Indigenous Student Education.” https://www.univcan.ca/priorities/Indigenous-education/.

Veracini, Lorenzo. 2010. Settler Colonialism: A Theoretical Overview. London: Palgrave Macmillan.

Walker, Margaret E. 2020. "Towards a Decolonized Music History Curriculum." Journal of Music History Pedagogy 10 (1): 1-19. http://www.ams-net. org/ojs/index.php/jmhp/article/view/310.

West Marvin, Elizabeth, Philip Ewell, Yayoi Uno Everett, Joseph Straus, and Ellie M. Hisama. 2019. "Reframing Music Theory." Paper presented at Society for Music Theory Annual Meeting, Columbus, OH, 9 November.

Wilder, Craig Stephen. 2013. Ebony and Ivy: Race, Slavery, and the Troubled History of America's Universities. New York: Bloomsbury.

Willinsky, John. 1998. Learning to Divide the World: Education at Empire's End. Minneapolis: University of Minnesota Press. 
Wolfe, Patrick. 2006. "Settler Colonialism and the Elimination of the Native." Journal of Genocide Research 8 (4): 387-409. https://doi. org/10.1080/14623520601056240.

\section{BIOGRAPHIES}

Robin Attas (she/her/hers) is a white settler music theorist living and working in Haudenosaunee and Anishinaabe territory as an educational developer at the Centre for Teaching and Learning at Queen's University in Kingston, Ontario. She is also cross-appointed in Queen's University's Dan School of Drama and Music. Robin supports teaching and learning development among faculty, staff, and students and remains active as a music theory researcher, presenting and publishing on topics centred upon music theory pedagogy. Her publications are available in journals including Music Theory Online, Music Theory Spectrum, the Canadian Journal of Higher Education, Music Theory Pedagogy, College Music Symposium, and MUSICultures.

Margaret E. Walker is professor of ethno/musicology at Queen's University in Kingston, which sits on Anishinaabe and Haudenosaunee Territory. Her monograph India's Kathak Dance in Historical Perspective (2014) focuses on the historiography of North Indian classical dance, and her research also explores gender, caste, diaspora, and colonialism. She has participated on two research teams exploring transnational music histories: the ERC-funded "Musical Transitions to European Colonialism" project at King's College London, and the Balzan "Towards a Global History of Music" project based at Oxford University. Her current work takes questions of global and decolonized music history into the classroom in a cluster of interrelated projects on curriculum. 